\title{
$\mathrm{SPT}$ 에너지효율 측정 롯드를 이용한 매입말뚝의 선단지지력 예측
}

\section{Prediction of End Bearing Capacity for Pre-Bored Steel Pipe Piles Using Instrumented Spt Rods}

\author{
남 문 석 ${ }^{1}$ Nam, Moon S. \\ 박 영 $\overline{ }^{2} \quad$ Park, Young-Ho \\ 박 용 석 ${ }^{3} \quad$ Park, Yong-Seok
}

\begin{abstract}
The standard penetration test (SPT) has been widely used because of its usability, economy, and many correlations with soil properties among other factors. In SPT, hammer energy is an important factor to evaluate and calibrate $\mathrm{N}$ values. To measure hammer energy, an instrumented SPT rod was developed considering that stress waves transferring on rods during SPT driving are the same as stress waves transferring on piles due to pile driving. Using this idea, an instrumented SPT rod with a pile driving analyzer was applied as a pile capacity prediction tool in this study. In order to evaluate this method, SPT and dynamic cone tests with the instrumented SPT rod were conducted and also 2 pile load tests were performed on pre-bored steel pipe piles at the same test site. End bearings were predicted by CAPWAP analysis on force and velocity waves from dynamic cone penetration tests and SPT. Comparing these predicted end bearings with static pile load tests, a new prediction method of the end bearing capacity using the instrumented SPT rod was proposed.
\end{abstract}

\section{요지}

국내외에서 널리 사용 중인 표준관입시험(Standard Penetration Test, SPT)은 작업의 용이성, 다양한 지반정수와 강도 정수를 결정방법 등의 장점을 지니고 있다. 이러한 SPT 수행시에 발생하는 해머 에너지는 N치의 산정 및 보정에 매우 중요한 영향인자가 된다. SPT시험시 해머 타격에 의하여 롯드로 응력파가 전달되는 현상이 말뚝 항타 시에 발생하는 현상과 동일하다하여 SPT에 PDA장비를 적용하여 관입에너지를 측정하는 방법이 개발되어 사용 중에 있다. 본 연구에서는 SPT 롯드를 말뚝으로 가정하여 SPT 에너지 효율 측정롯드를 SPT시험과 동적콘관입시험에 적용하여 얻어진 힘과 속도의 파형을 매칭기법(CAPWAP, CAse Pile Wave Analysis Program) 분석을 수행하여 매입말뚝에 대한 극한선단지지력을 예측하는 기법을 제안하였다. 또한, SPT 에너지 효율 측정롯드에서 예측된 선단지지력과 실물 말뚝정재하시험을 통하여 산정된 선단지지력을 비교분석하였다. 연구결과를 토대로 SPT나 동적콘관입시험을 통하여 매입말뚝의 지지력을 간편하게 예측할 수 있는 경험식을 제시하였다.

Keywords : SPT, Dynamic cone tests, Instrumented SPT rods, End bearing, Pre-bored steel pile piles

\footnotetext{
1 정회원, Member, Senior Researcher, Research Institute, Korea Expressway Corporation, Korea, Tel: +82-31-371-3348, Fax: +82-31-371-3379, moonsnam@gmail.com, Corresponding author, 교신저자

2 비회원, Research Director, Research Institute, Korea Expressway Corporation, Korea

3 비회원, Researcher, Research Institute, Korea Expressway Corporation, Korea

* 본 논문에 대한 토의를 원하는 회원은 2014년 6월 30일까지 그 내용을 학회로 보내주시기 바랍니다. 저자의 검토 내용과 함께 논문집에 게재하여 드립니다.
} 


\section{Introduction}

The standard penetration test (SPT), which has been widely used in Korea, has many usability and suitability whose in determining various soil properties or strength parameters. For intermediate material (IGM) or soft rock cores are recovered in fragments because of joint structures, a dynamic cone penetration test such as Texas cone penetrometer test (TCPT) was proposed as a surrogate method to quantify geomaterial strength of the IGM or soft rock (Nam and Vipulanandan, 2010). During SPT or dynamic cone penetration tests, hammer energy is an important factor to evaluate and calibrate $\mathrm{N}$ values. In order to measure hammer energy, an instrumented SPT rod was developed considering that stress waves transferring on rods during SPT or cone driving are the same as stress waves transferring on piles due to pile driving (Lee and Lee, 2005).

From the instrumented rod, the pile drive analyzer (PDA), a high-strain dynamic test to determine the force and velocity response of a pile to an impact force applied axially by a driving hammer at the pile top, collected strain and acceleration measurements during hammer driving. The PDA immediately converted these strain and acceleration signals to force and velocity values. After high strain dynamic data were collected in the field, they were analyzed with a case pile wave analysis program (CAPWAP). Finally, the CAPWAP estimated the end bearing capacity of piles.

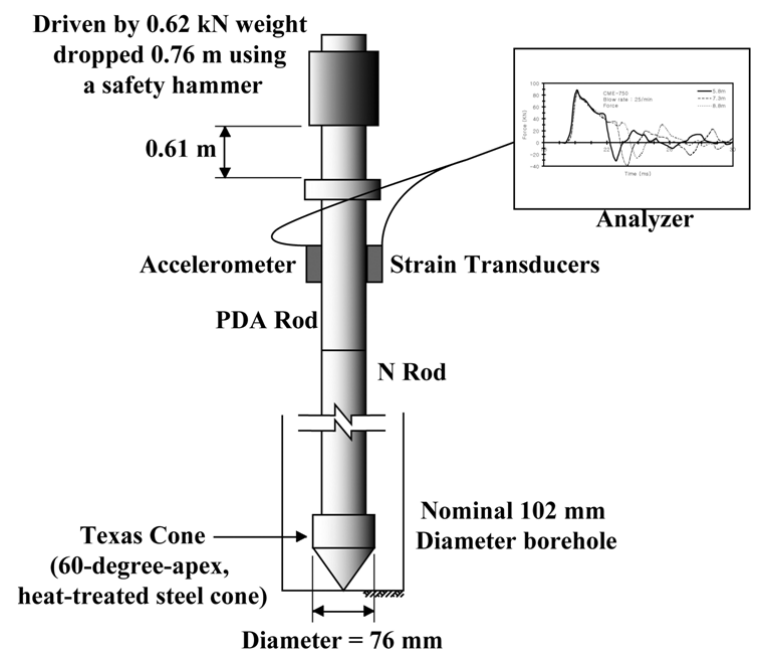

Fig. 1. Schematic of end bearing capacity prediction using instrumented SPT rods
The CAPWAP is based on the wave equation model, which analyses the pile as a series of elastic segments and the soil as a series of elasto-plastic elements with damping characteristics, where stiffness represents static soil resistance and damping represents dynamic soil resistance (Alvarez, et. al, 2006).

By applying the instrumented SPT rod and the PDA to SPT or dynamic cone penetration tests, these tests can develop stress waves transferring on rods during SPT or cone driving. Then, stress waves can be taken by the PDA and analyzed to estimate unit bearing capacities of piles by the CAPWAP as illustrated in Fig. 1. The instrumented SPT rod was applied to SPT or dynamic cone tests, such as Texas cone penetrometer test (TCPT), modified Texas cone penetrometer test (MTCPT) and Korea Expressway Corporation cone penetrometer test (KCPT). MTCPT and KCPT were newly applied to easy access for the cone into the NX hole because the diameter of the TCPT cone is almost the same as the NX boring size widely used in Korea.

Since the SPT is an essential in-situ test to design pile capacities, the SPT with the instrumented rod can be a simple index for estimating pile capacities. In order to evaluate this concept, SPT and cone penetration tests and a total of 2 pile load tests were performed on the field site in this study.

\section{Test Site and Ground Condition}

To predict the end bearing capacity of piles with

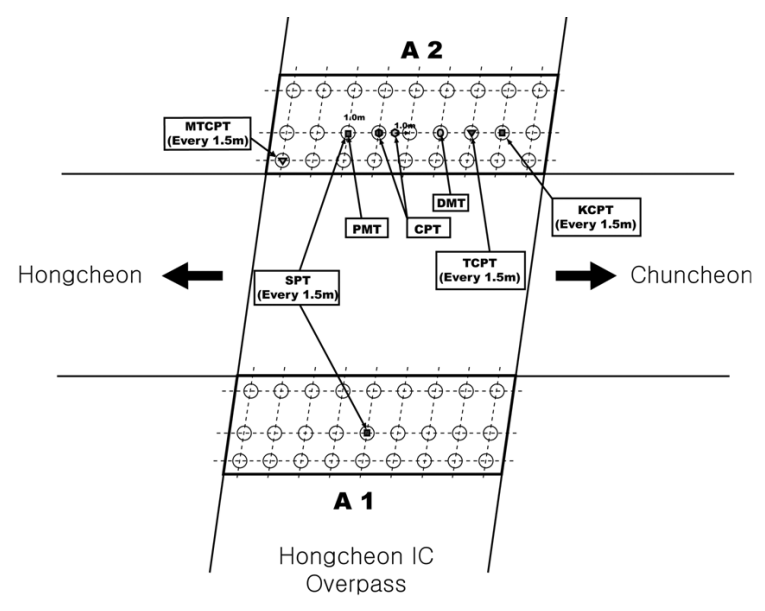

Fig. 2. Test site 
instrumented SPT rods, SPT and several types of dynamic cone tests, ground investigations and field pile load tests were conducted. The test site was located at the construction site of Donghongcheon Interchange overpass in the ChuncheonHongcheon Expressway in Korea. For the site investigation, the following tests were performed as marked in Fig. 2, such as "Standard Penetration Test (SPT), KS F2307-87", "Texas Cone Penetration Test (TCPT)", "Modified Texas Cone Penetration Test (MTCPT)", "Korea Expressway Corporation Cone Penetration Test (KCPT)", "Piezoncone Test (CPT)", "Pressuremeter Test (PMT)", and "Dilatometer Test (DMT)." Detailed results of test results except SPT and dynamic cone tests can be referred in Park et. al (2010). Ground condition of the test sites was determined by boring tests and elastic wave tests. The ground profile consisted of 6 layers: reclamation soil (surface to $8.5 \mathrm{~m}$ ), paddy soil (8.5 to $9.2 \mathrm{~m}$ ), colluvium soil $(9.2$ to $13.5 \mathrm{~m})$, weathered soil $(13.5$ to $18.3 \mathrm{~m})$, weathered rock (18.3 to $20.3 \mathrm{~m})$ and soft rock (20.3 $\mathrm{m}$ to $33.6 \mathrm{~m})$.

Based on the results of SPT and several types of dynamic cone tests with instrumented SPT rods, CAPWAP was carried out to predict the end bearing capacity before piling constructions; and then, these predicted results were compared with results obtained from pile load tests on production piles.

\section{Spt and Dynamic Cone Penetration Tests}

In this study, an automatic hammer with instrumented SPT rod was used for SPT, TCPT, MTCPT and KCPT. Table 1 and Fig. 3 show their corresponding details. Instrumented SPT rods with a PDA were used to get force and velocity waves. Then, these waves went through CAPWAP to calculate end bearing capacities.

Two sets of SPT were conducted at intervals of 1.5 $\mathrm{m}$ in $\mathrm{A} 1$ and $\mathrm{A} 2$ as shown in Fig. 3. One set of TCPT was conducted at intervals of $1.5 \mathrm{~m}$ as marked on Fig. 3 according to the Texas Department of Transportation geotechnical design manual (TxDOT, 2000). Cones were connected to the bottom of the rods, and were lowered to the bottom of boring holes. Then, the hammer $(0.76$ $\mathrm{KN}$ ) connected to the top of the rods was dropped from a height of $61 \mathrm{~cm}$ to measure penetration depth. In regular soils, just as the SPT, the number of hits needed to penetrate $30 \mathrm{~cm}$ into a cone was calculated. When the ground was too strong and it was difficult to penetrate $30 \mathrm{~cm}$, the cone was hit 100 times, and the penetrating depth at that time was written, for example, as 30/100 (30 mm penetrated at 100 hits). Since the cone is strong, TCPT can be applied to intermediate geomaterial (IGM) or rocks that the SPT cannot penetrate (Nam, 2006).

Since the diameter of the TCPT cone is almost the same as the NX boring size widely used in Korea, MTCPT, that reduces the TCPT cone diameter to $72 \mathrm{~mm}$ with the same area ratio of the cone to sleeve for TCPT, is conducted

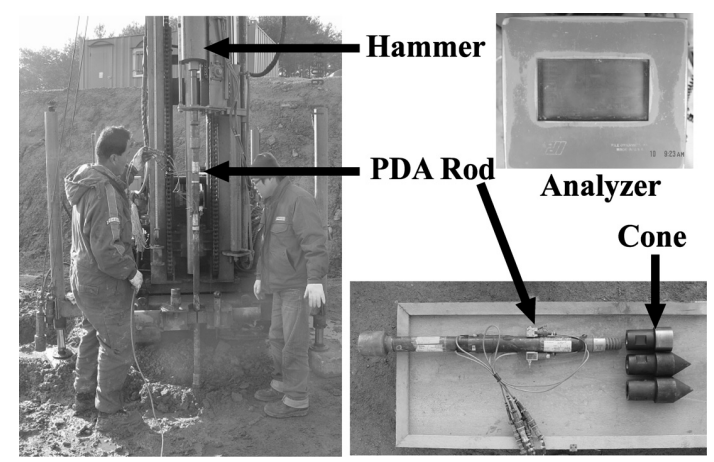

(a) Photo of dynamic cone tests with instrumented SPT rod
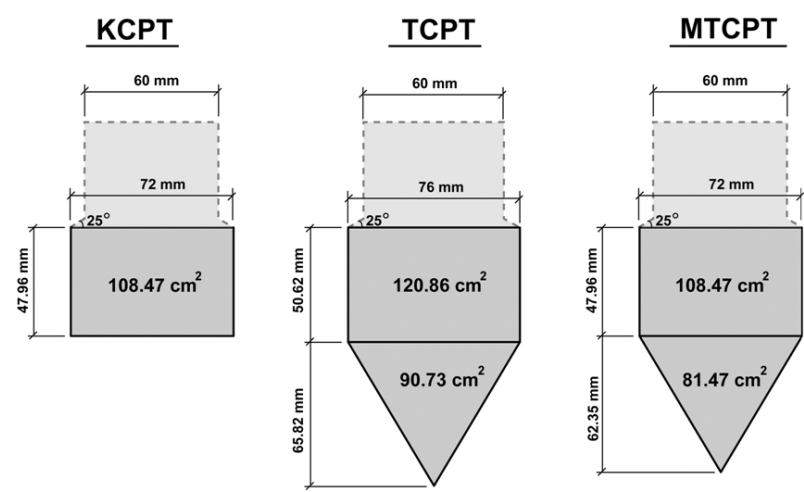

(b) Dimension of dynamic cones

Fig. 3. Dynamic cone tests with instrumented SPT rods

Table 1. Details of drilling rigs

\begin{tabular}{c|c|c|c}
\hline Equipment & Excavation Method & Hammer Lifting and Falling & Instrument \\
\hline Automatic Hammer & Water Jetting Rotary Boring & Chain Rotating & PDA, SPT Rod \\
\hline
\end{tabular}



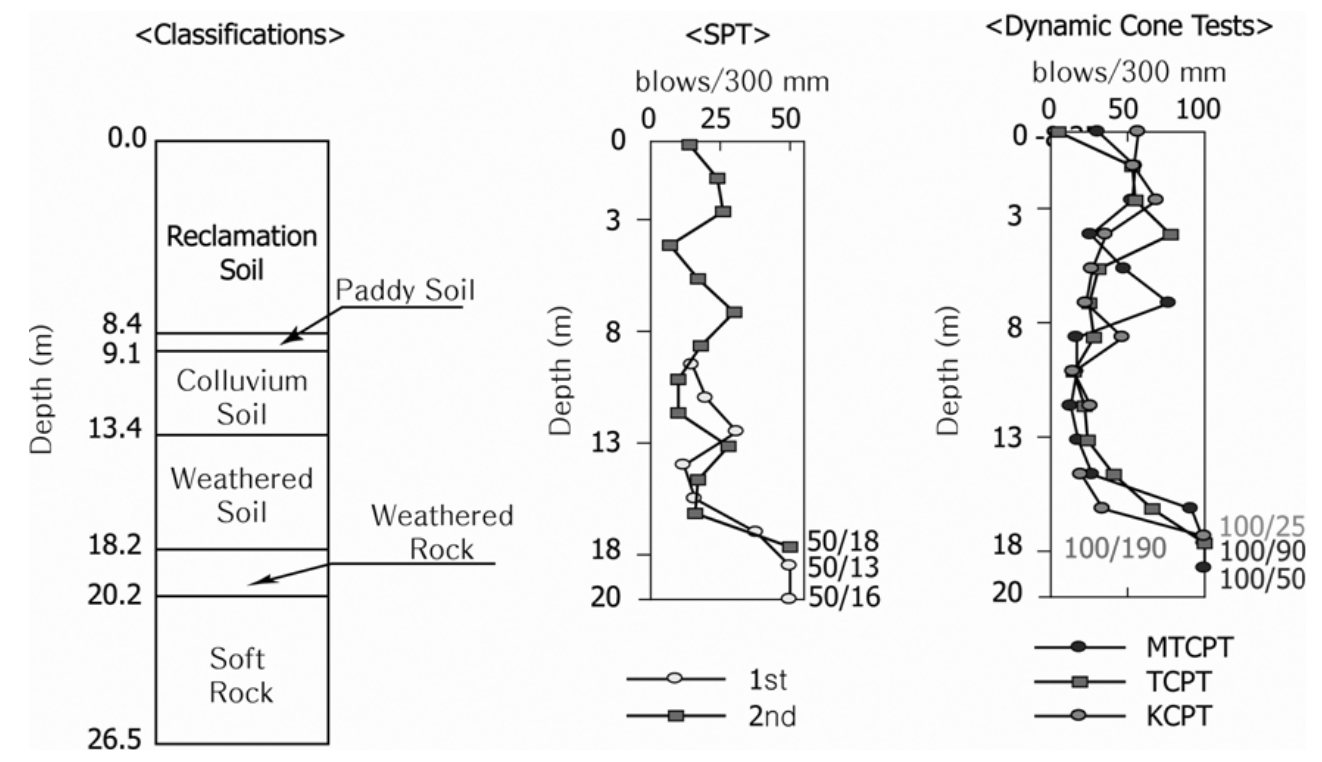

Fig. 4. SPT and dynamic cone tests results

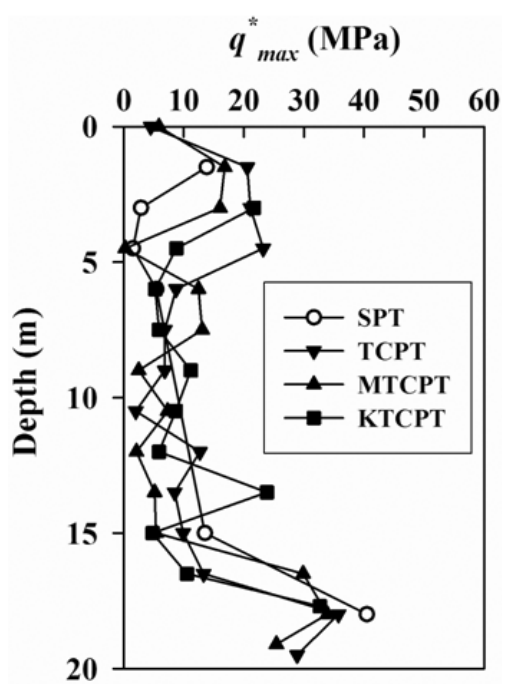

Fig. 5. CAPWAP analysis results

at the test site as shown in Fig. 3. KCPT, that removes the cone part from MTCPT as shown in Fig. 3, was also applied in this study. Hence, tests to analyze differences of end bearing capacities of piles obtained from SPT and various dynamic cone penetration tests including TCPT, SPT, MTCPT and KCPT installed with the instrumented SPT rods were conducted at the test site.

Fig. 4 shows the results of SPT and dynamic cone penetration tests (TCPT, MTCPT and KCPT). The results from dynamic cone penetration tests were similar regardless of their tests, and their distribution in layers was similar to results obtained from SPT.
These test results obtained from dynamic cone penetration tests and SPT were analyzed in CAPWAP to estimate predicted ultimate end bearing capacities which are shown in Fig. 5. In this study, an ultimate end bearing capacity predicted by dynamic cone penetration tests and SPT with the instrumented SPT rod was named as $q^{*} \max$. The predicted end bearing capacities of weathered rock, where the pile tip is located, were distributed between $31 \mathrm{MPa}$ and $45 \mathrm{MPa}$. Even though there were some variations in each test, when there was inconsistency of grounds, distribution of $q^{*}$ max was relatively similar in each test.

\section{Pile Load Tests}

To evaluate $q_{\text {max }}^{*}$ obtained from CAPWAP analysis on dynamic cone penetration tests and SPT with instrumented SPT rods, two static pile load tests were conducted on two production piles (TP-1 and TP-2). The pre-bored steel pipe piling method was used for test pile construction, which is very common in Korea. Construction procedure is shown in Fig. 6 and details are as follows: the auger was used to excavate weathered rock and the steel pipe pile with a diameter of $508 \mathrm{~mm}$ was inserted and driven. After the final driving, cement grout was injected to pile bases and sides.

After cement grout was cured, static pile load tests for the 

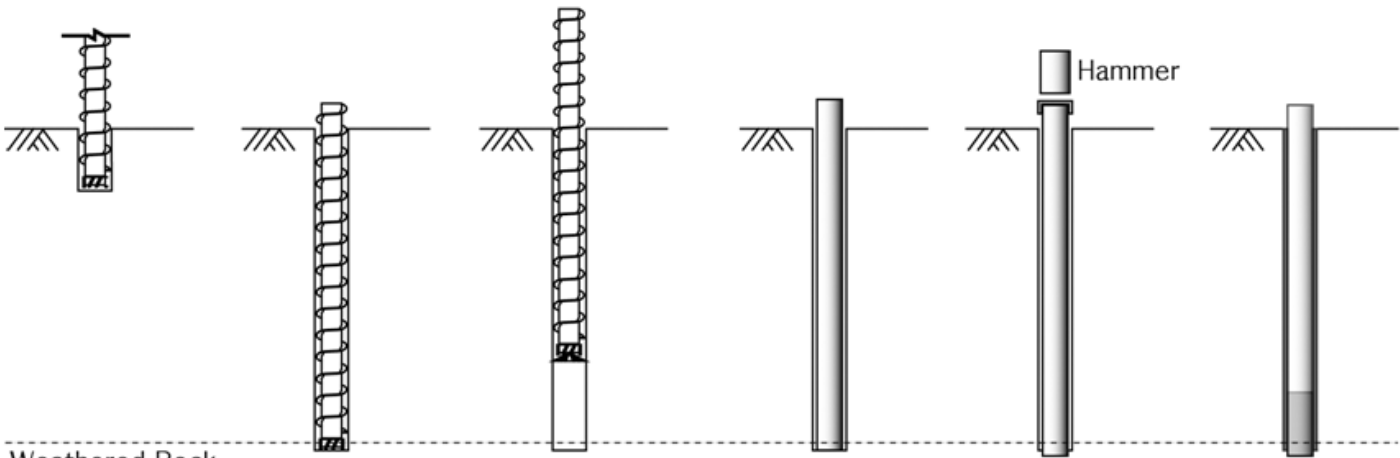

Fig. 6. Construction procedure of pre-bored steel pipe pile
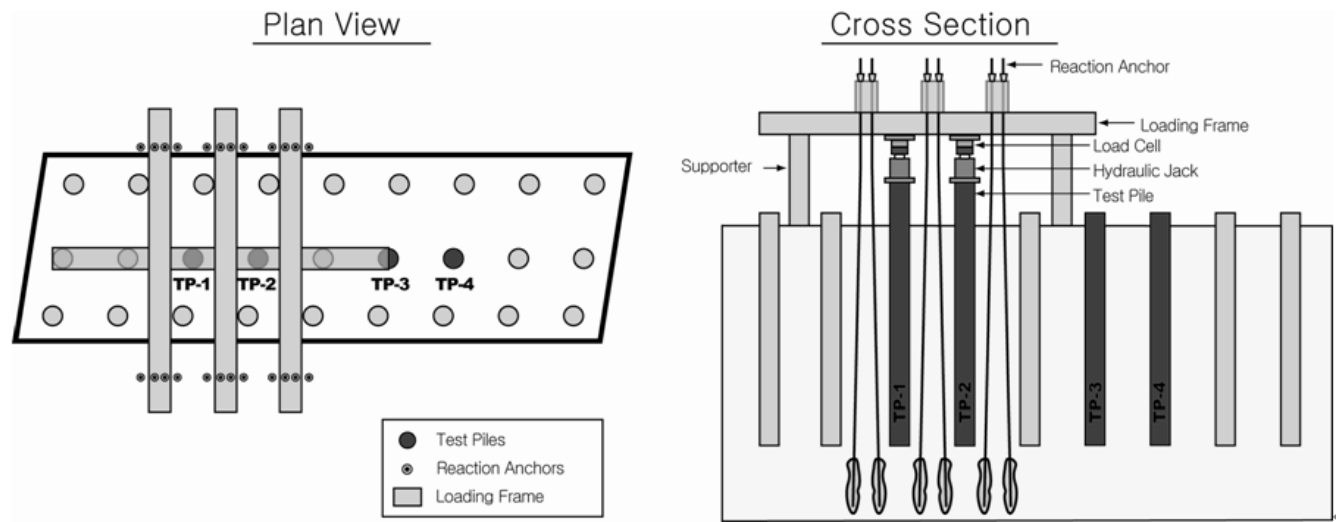

(a) Schematic of static pile load tests

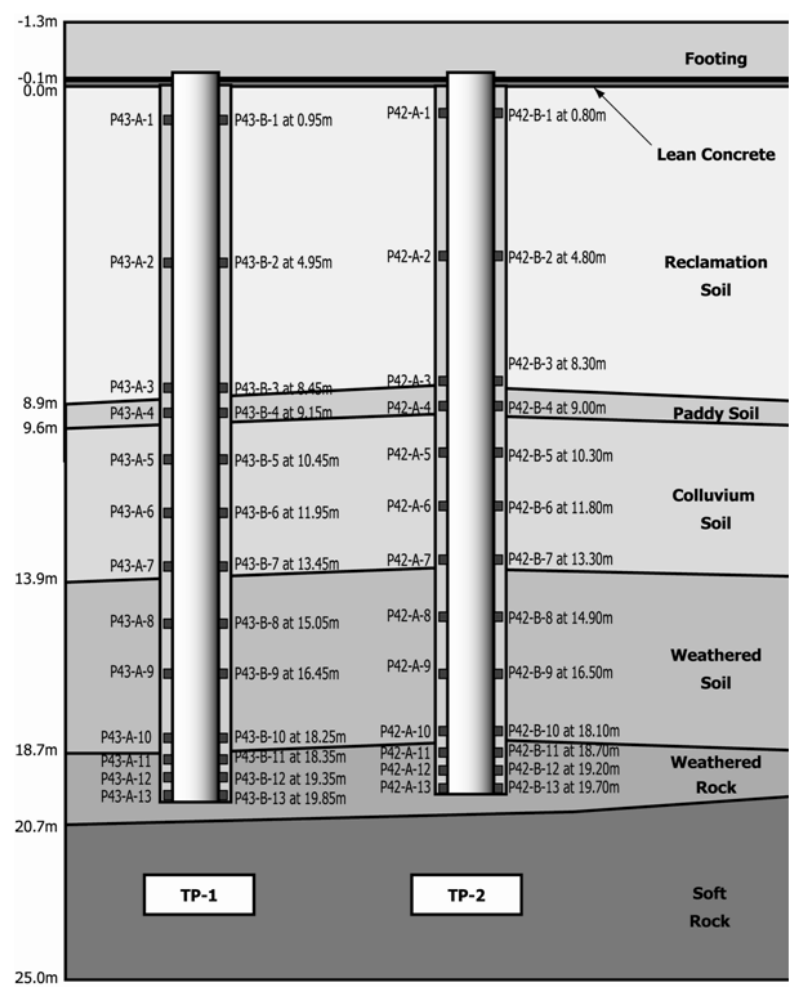

(b) Instrumentations of test piles

Fig. 7. Static pile load tests and instrumented test piles 


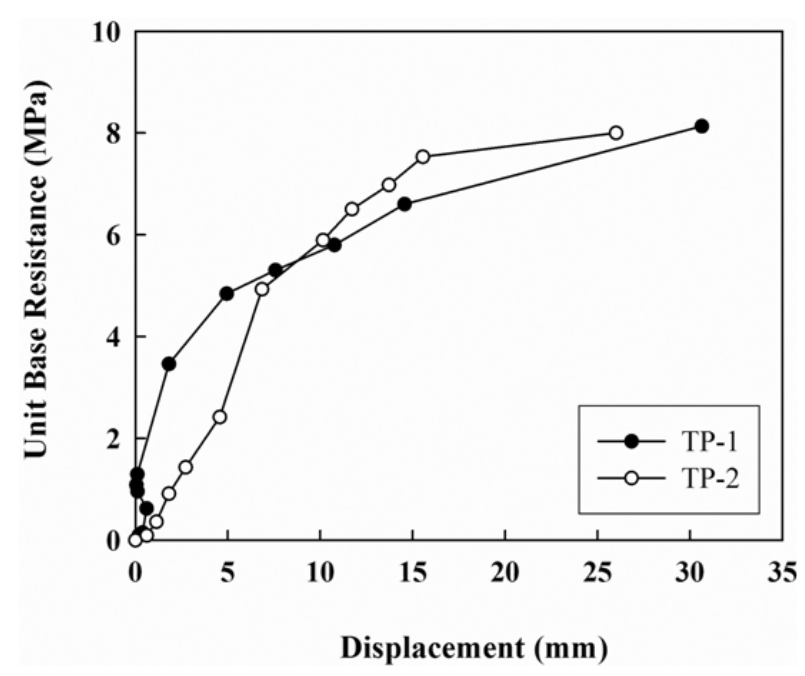

Fig. 8. End bearing capacities of test piles from load test results

two fully instrumented test piles were conducted with load transfer analysis. Information of test piles instrumentation and static pile load tests are shown in Fig. 7. Based on the results of static pile load tests, $q-w$ (end bearing-displacement) curves for test piles are produced as shown in Fig. 8. From the $q-w$ curve, ultimate end bearing capacities by the load test $\left[q_{\max }\right.$ (load test) $]$ of TP-1 and TP-2 could be determined as about 8.1 MPa and 7.7 MPa by taking their maximum values.

\section{Comparison with Pile Load Test Results}

To compare $q_{\text {max }}^{*}$ with $q_{\max }$ (load test), the average of $q_{\max }^{*}$ values around the pile tip $(18 \mathrm{~m} \sim 21 \mathrm{~m})$ was selected as 34.8 MPa from Fig. 5, and the average of $q_{\max }$ (load test) for TP-1 and TP-2 was also selected as 7.9 MPa form Fig. 8. The $q_{\max }$ (load test) was $23 \%$ of $q_{\max }^{*}$. Based on the limited data, an ultimate end bearing capacity of a pile $\left(q_{\max }\right)$ can be predicted as follows:

$$
q_{\max }=0.23 q_{\max }^{*}
$$

where, $q^{*}{ }_{\max }$ is an ultimate end bearing capacity predicted by dynamic cone penetration tests and SPT with the instrumented SPT rod.

It is noted that this correlation can be applied only to pre-bored steel pipe piles with a diameter of $508 \mathrm{~mm}$ embedded into weathered rocks. This correlation should be applied to other types of piles only after careful consideration. This study suggests a prediction method for the end bearing capacity of the pile by conducting CAPWAP analysis with instrumented SPT rods for SPT or dynamic cone penetration tests. If further studies are carried out for various grounds and piles to gain more reliability, this prediction method can have a wide variety of uses.

\section{Conclusions}

In this study, force and velocity waves obtained by applying instrumented SPT rods for SPT, and dynamic cone penetration tests were analyzed with CAPWAP to predict the end bearing capacity of the pile. Then, this prediction result was compared with that from field static pile load tests. Results of this study are as follows:

(1) In various dynamic cone penetration tests, the number of hits and penetration values were similar regardless of test types, and distribution results of SPT and dynamic cone penetration tests were similar according to change in ground layers.

(2) Predicted end bearing capacity $\left(q_{\max }^{*}\right)$ was estimated by conducting the CAPWAP analysis on force and velocity waves obtained from dynamic cone penetration tests and SPT. Although there were some variations in $q^{*}$ max according to test methods, considering the inconsistency of ground, $q^{*}{ }_{\max }$ distribution was relatively similar in each test.

(3) To get end bearing capacities $\left(q_{\max }\right)$ of piles by SPT or cone penetration tests with the instrumented rod, two pile load tests were conducted to get measured end bearing capacities $\left[q_{\max }\right.$ (load test) $]$ for comparing predicted and measured capacities. Based on the comparison of $q_{\max }^{*}$ and $q_{\max }$ (load test), a correlation of $q_{\max }=0.23 q_{\max }^{*}$ was proposed.

(4) Using this correlation of $q_{\max }=0.23 q^{*}{ }_{\max }$, end bearing capacities $\left(q_{\max }\right)$ of piles can be easily determined by SPT or cone penetration tests with the instrumented 
rod. However, this correlation is based on pre-bored steel pipe piles with a diameter of $508 \mathrm{~mm}$ embedded into weathered rocks and should be applied to other types of piles only after careful consideration.

\section{References}

1. Alvarez, C., Zuckerman, B., and Lemke, J. (2006), "Dynamic Pile Analysis Using CAPWAP and Multiple Sensors", GeoCongress 2006: Geotechnical Engineering in the Information Technology Age, ASCE, pp.1-5.

2. Lee, C. H. and Lee, W. J. (2005), "Ratio of Hammer Energy and Dynamic Efficiency of Standard Penetration Test", Journal of Korean Geotechnical Society, Korean Geotechnical Society, Vol.21. No.9, pp.5-12.

3. Nam, M. S. (2006), "Design of IGM Socketed Drilled Shafts Using
Texas Cone Penetrometer Tests", Journal of Korean Geotechnical Society, Korean Geotechnical Society, Vol.22 No.10, pp.55-68.

4. Nam, M. S. and Vipulanandan, C. (2010), "Relationship between Texas Cone Penetrometer Tests and Axial Resistances of Drilled Shafts Socketed in Clay Shale and Limestone", Journal of Geotechnical and Geoenvironmental Engineering, ASCE, Vol.136, No. 8, pp.1161-1165.

5. Park, Y. H., Kim, N. Y., Lee, B. J., Lee, K. H., Kim, I. H., and Park, Y. S. (2010), "Practiacl Application of Semi-Integral Abutment Bridge”, Report No. EXTRI-2011-12-534.9607, Expressway \& Transportation Research Institute, Korea Expressway Corporation.

6. TxDOT (Texas Department of Transportation) (2000), “Geotechnical Manual (On-line Version)", Texas Department of Transportation, Bridge Division, Austin, Texas.

Received : November $1^{\text {st }}, 2013$

Revised : November $29^{\text {th }}, 2013$

Accepted : December $3^{\text {rd }}, 2013$ 